\title{
Intergeneric transfer of ribosomal genes between two fungi
} Jiatao Xie ${ }^{1,2}$, Yanping Fu1, Daohong Jiang*1,2, Guoqing Li ${ }^{1,2}$, Junbin Huang1, Bo Li1 ${ }^{1}$, Tom Hsiang 1,3 and Youliang Peng ${ }^{4}$

\author{
Address: ${ }^{1}$ The Key Lab of Plant Pathology of Hubei Province, College of Plant Science and Technology, Huazhong Agricultural University, Wuhan \\ 430070, Hubei, P R China, 2National Key Lab of Agricultural Microbiology, Huazhong Agricultural University, Wuhan 430070, Hubei, P R China, \\ ${ }^{3}$ Department of Environmental Biology, University of Guelph, Guelph, ON, Canada and ${ }^{4}$ Department of Plant Pathology, China Agricultural \\ University, Beijing, 100094, P R China \\ Email: Jiatao Xie - xjt9902@webmail.hzau.edu.cn; Yanping Fu - yanpingfu@mail.hzau.edu.cn; \\ Daohong Jiang* - daohongjiang@mail.hzau.edu.cn; Guoqing Li - guoqingli@mail.hzau.edu.cn; \\ Junbin Huang - junbinhuang@mail.hzau.edu.cn; Bo Li - bolida@webmail.hzau.edu.cn; Tom Hsiang - thsiang@uoguelph.ca; \\ Youliang Peng - pengyl@cau.edu.cn \\ * Corresponding author
}

\section{Published: 18 March 2008}

BMC Evolutionary Biology 2008, 8:87 doi:10.1186/147/-2/48-8-87
Received: 20 December 2007

Accepted: 18 March 2008

This article is available from: http://www.biomedcentral.com/I47/ -2/48/8/87

(C) 2008 Xie et al; licensee BioMed Central Ltd.

This is an Open Access article distributed under the terms of the Creative Commons Attribution License (http://creativecommons.org/licenses/by/2.0), which permits unrestricted use, distribution, and reproduction in any medium, provided the original work is properly cited.

\begin{abstract}
Background: Horizontal gene transfer, also called lateral gene transfer, frequently occurs among prokaryotic organisms, and is considered an important force in their evolution. However, there are relatively few reports of transfer to or from fungi, with some notable exceptions in the acquisition of prokaryotic genes. Some fungal species have been found to contain sequences resembling those of bacterial genes, and with such sequences absent in other fungal species, this has been interpreted as horizontal gene transfer. Similarly, a few fungi have been found to contain genes absent in close relatives but present in more distantly related taxa, and horizontal gene transfer has been invoked as a parsimonious explanation. There is a paucity of direct experimental evidence demonstrating the occurrence of horizontal gene transfer in fungi.
\end{abstract}

Results: We found a fungal field isolate from rice (Oryzae sativa) that contains ribosomal DNA sequences from two species of fungal rice pathogens (Thanatephorus cucumeris and Ceratobasidium oryzae-sativae). This field isolate has four types of ribosomal DNA internal transcribed spacers (ITS), namely pure ITS of $C$. oryzae-sativae, which was dominant in this field isolate, pure ITS of $T$. cucumeris, and two chimeric ITS, with ITSI derived from C. oryzae-sativae and ITS2 from $T$. cucumeris, or ITSI from T. cucumeris and ITS2 from C. oryzae-sativae. The presence of chimeric forms indicates that the intergeneric hybrid was not merely composed of nuclei from the parental species, but that nuclear fusion and crossing over had taken place.

Conclusion: Hyphae of $T$. cucumeris and C. oryzae-sativae are vegetatively incompatible, and do not successfully anastomose. However, they parasitize the same host, and perhaps under the influence of host enzymes targeted to weaken pathogen cells or in dying host plant tissue, the fungal hyphae lost their integrity, and normal vegetative incompatibility mechanisms were overcome, allowing the hyphae to fuse. Based on the presence of other similarly anomalous isolates from the field, we speculate that these types of intergeneric hybridization events and occurrences of horizontal gene transfer may not be so rare in the field. 


\section{Background}

Horizontal gene transfer (HGT), also called lateral gene transfer, is known to occur among prokaryotic organisms, and is considered an important force in their evolution [1], but HGT is less well known among eukaryotes [2]. Based on a study of known protein domain families and publicly available sequences, there is evidence for HGT among more than $50 \%$ of archaea, between $30 \%$ to $50 \%$ of bacteria, and less than $10 \%$ of eukaryotes [3].

The role of HGT in the evolution of fungi was recently reviewed [4], and the authors speculated that the mode of feeding and large surface area in association with other organisms allow fungi a greater opportunity for HGT than other eukaryotes. Among fungi, some species have been found to contain sequences resembling those of bacterial genes, but such sequences were absent in other fungal species, and this was interpreted as HGT [5-10]. Transfer of a supernumerary chromosome between vegetatively incompatible biotypes of the phytopathogenic fungus, Colletotrichum gloeosporioides, was obtained under laboratory conditions [11]. Gene clusters encoding for epipolythiodioxopiperazines, which are a class of secondary metabolite toxins, have been found in various ascomycete fungi, but the phylogeny of these gene clusters was not concordant with that of the organisms in which they were found. [12]. A nitrate assimilation gene cluster was thought to have been transferred first from Oomycota to Dikarya (Ascomycota and Basidiomycota), and then more recently from a basdiomycete to the ascomycete Trichoderma reesei, which allowed this fungus to better exploit its new niche [13].

In a review of the evolution of virulence genes in fungi [14], the authors speculate that HGT is important in their origin in different pathogenic species, and may facilitate the emergence of new pathogens. They also noted the phenomenon where virulence genes are present in clusters. For example, a cluster of genes similar to those in pea was found on a supernumerary chromosome of three different fungi pathogenic to pea [15]. The authors of the review also speculate that the high density of transposable and repetitive elements frequently observed near putative virulence genes somehow allows or even facilitates the clustering of virulence genes, and that regions characterised by particular sequences may be more susceptible to HGT.

One group of genes that has not been demonstrated to be subjected to HGT encodes for ribosomal RNA [3]. These genes are found in the ribosomal DNA (rDNA) region, and form what has been called the ribosomal cassette. The rRNA combine with protein molecules to form ribosomes that function in protein synthesis. Because of the high demand for protein synthesis, there are multiple copies repeated tens to thousands of times in a genome [16]. Eukaryotes have rDNA cassettes formed by the small subunit (18S), the internally transcribed spacer (ITS) 1 , the $5.8 \mathrm{~S}$ gene, the ITS2, the large subunit $(28 \mathrm{~S})$ and the intergenic spacer region. The differences between rDNA sequences allow for studies of phylogenetic relationships over a wide range of taxonomic levels [17].

In the current study, we found that DNA of a field fungal strain from rice (Oryzae sativa), was amplified with two sets of specific, normally diagnostic rDNA primers: one set for the sheath blight fungus, and the other for the sheath blot fungus. Sheath blight, caused by Thanatephorus cucumeris, is a notorious disease of rice with serious losses every year [18]. Ceratobasidium oryzae-sativae is another pathogen of rice, which causes sheath blot. These two pathogens both have their anamorphs (asexual stage) in the fungal form-genus Rhizoctonia, but are considered distantly related. Further testing with the fungal strain from the field using species-specific primers, Southern hybridization, DNA cloning, and DNA sequencing yielded results implying that gene transfer had occurred between rDNA genes of these two species of pathogenic fungi, and that genetic recombination had occurred at the $5.8 \mathrm{~S}$ gene.

\section{Results and Discussion}

In November 2004, a fungal strain, named RCOL-1, was isolated from a typical rice sheath blight lesion in a field at Huazhong Agricultural University in Central China. The growth rate of RCOL- 1 was slower than the average for either of the two major fungal rice pathogens Thanatephorus cucumeris or Ceratobasidium oryzae-sativae. This isolate also showed abnormal colony formation on PDA (potato dextrose agar), with sclerotia irregularly distributed compared to the two rice pathogens (Fig 1). RCOL-1 was also found to be avirulent when inoculated onto plant host tissue. DAPI staining (4',6-diamidino-2-phenylindole stain, [19]) showed that the distribution of nuclei in individual cells of RCOL-1 was not uniform (Fig $2)$, with some cells containing only one nucleus $(1.3 \%$ out of 1210 cells counted), some with two nuclei $(95.9 \%)$, and some multinucleate $(2.8 \%)$ with up to 5 nuclei observed per cell. In contrast, cells of T. cucumeris consistently contain multiple nuclei, and C. oryzae-sativae has two nuclei in each cell [20].

DNA of RCOL-1 was tested using primers specific for either T. cucumeris or C. oryzae-sativae [18] based on the internal transcribed spacer (ITS) of the multi-copy nuclear ribosomal DNA genes (rDNA). RCOL-1 was found to have target bands of both fungal species (Fig 3). Furthermore, Southern blot of genomic DNA showed that the DNA of RCOL-1 could hybridize with either of the two probes, but the DNA of isolate WH-1 (T. cucumeris) or WH-87 (C. oryzae-sativae) would only hybridize with their 


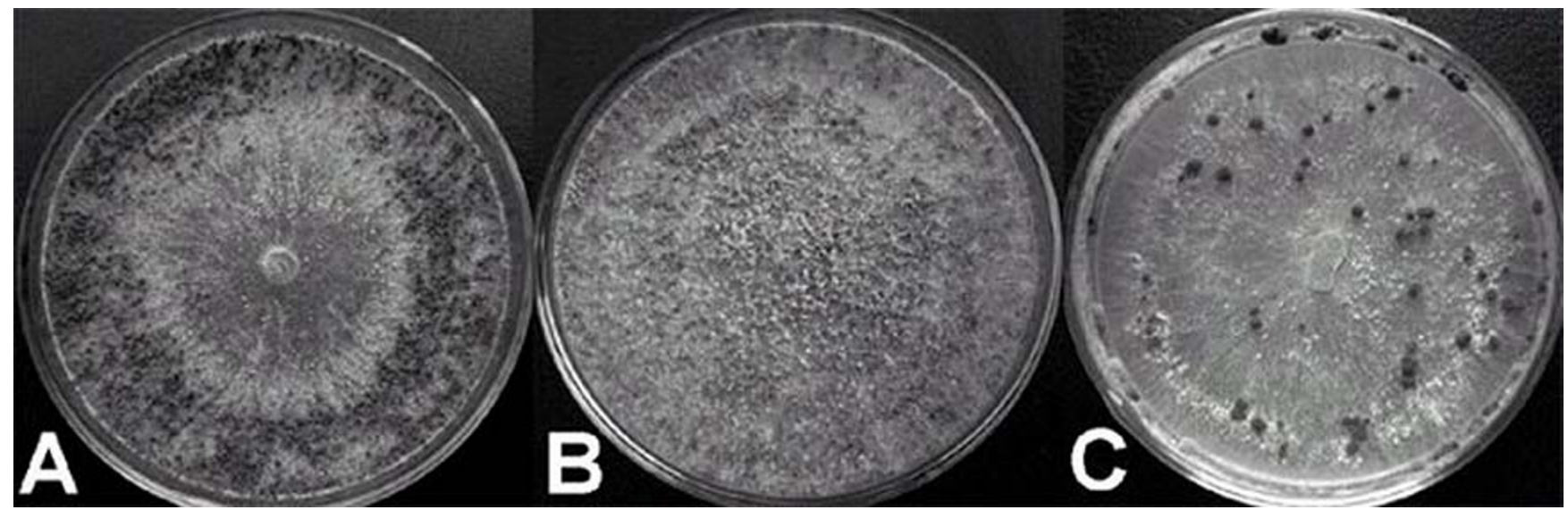

Figure I

Colony morphology of (A) Ceratobasidium oryzae-sativa WH-87, (B) Strain RCOL-I and (C) Thanatephorus cucumeris WH-I, showing abnormal distribution of sclerotia of strain RCOL-I when grown at $25^{\circ} \mathrm{C}$ on PDA for 10 days.

respective probes (Fig. 4). These results confirmed that RCOL-1 contained rDNA sequence from both C. oryzaesativae and T. cucumeris.

In addition to primer GMRS-3 which was based on the ITS2 sequence of T. cucumeris [18], three other primers were used which were designed from the ITS1 sequence of

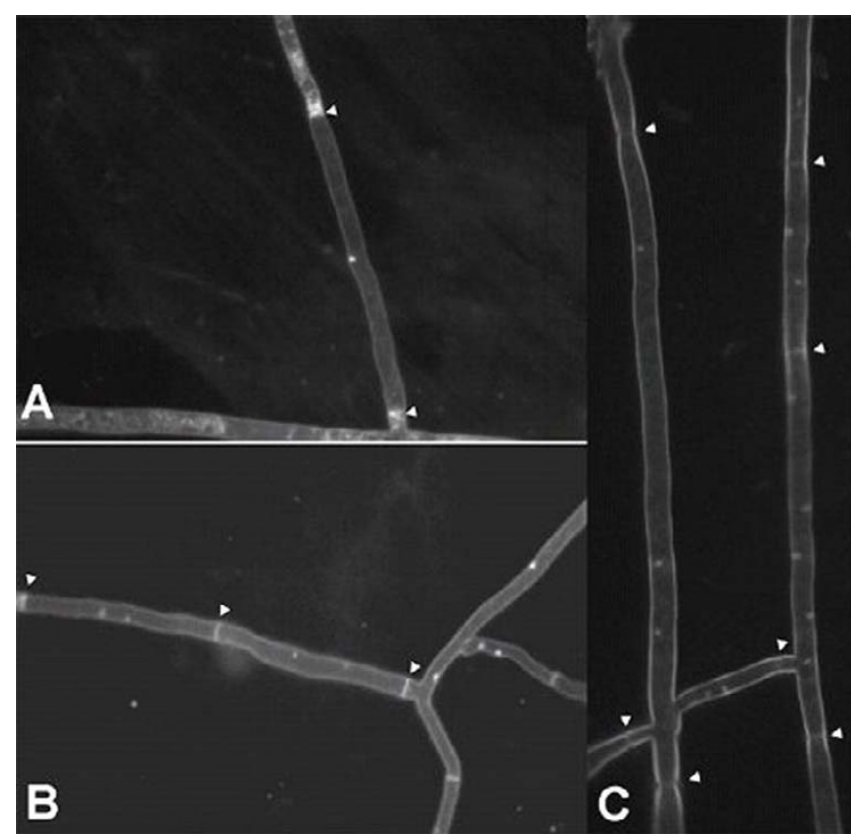

Figure 2

DAPI-stained nuclei in hyphae of strain RCOL-I: (A) only one nucleus in one cell; (B) two nuclei per cell; and (C) two or more nuclei per cell.
T. cucumeris (P-RSITS1-F), or the ITS1 (P-COITS1-F) or ITS2 (P-COITS2-R) of C. oryzae-sativae. The two forward and two reverse primers were used in all combinations. The amplification products (Fig 5) were sequenced, and these showed that RCOL-1 contained four types of ITS sequences, ones fully matching either $C$. oryzae-sativae (GenBank Accession DQ307249) or T. cucumeris (DQ307250), and two types of chimeric sequences: ITS1 DNA from C. oryzae-sativae with ITS2 DNA from $T$. cucumeris (DQ307251) or ITS1 DNA from T. cucumeris with ITS2 DNA from C. oryzae-sativae (DQ307252). The 747 bp alignment of the ITS of C. oryzae-sativae (712 bp) with $T$. cucumeris (718 bp) showed $79.5 \%$ identity, further demonstrating that these are distinct species, although they both have their anamorphs in the form-genus Rhizoctonia.

Clones were generated from polymerase chain reaction (PCR) products derived using universal fungal primers, ITS1 and ITS4 [17], and these clones were tested with the four pairs of primers mentioned above. Among the 500 clones, 499 were found to contain a complete ITS cassette of C. oryzae-sativae, but one of the clones was chimeric, with ITS1 of C. oryzae-sativae and ITS2 of T. cucumeris, based on primer amplification and DNA sequencing. To specifically detect the presence of T. cucumeris DNA, genomic DNA of RCOL-1 was amplified with the primer pair ITS1 (non-specific) and GMRS-3 (specific for the ITS2 region of T. cucumeris). The PCR product was used to generate 66 clones which were tested with the primer pairs COITS-F and GMRS-3 (for chimeric C. oryzae-sativae ITS1 and T. cucumeris ITS2), and P-RSITS1-F and GMRS-3 (for pure T. cucumeris ITS), giving 49 and 17 clones, respectively. Similarly, DNA of RCOL-1 was amplified with the 


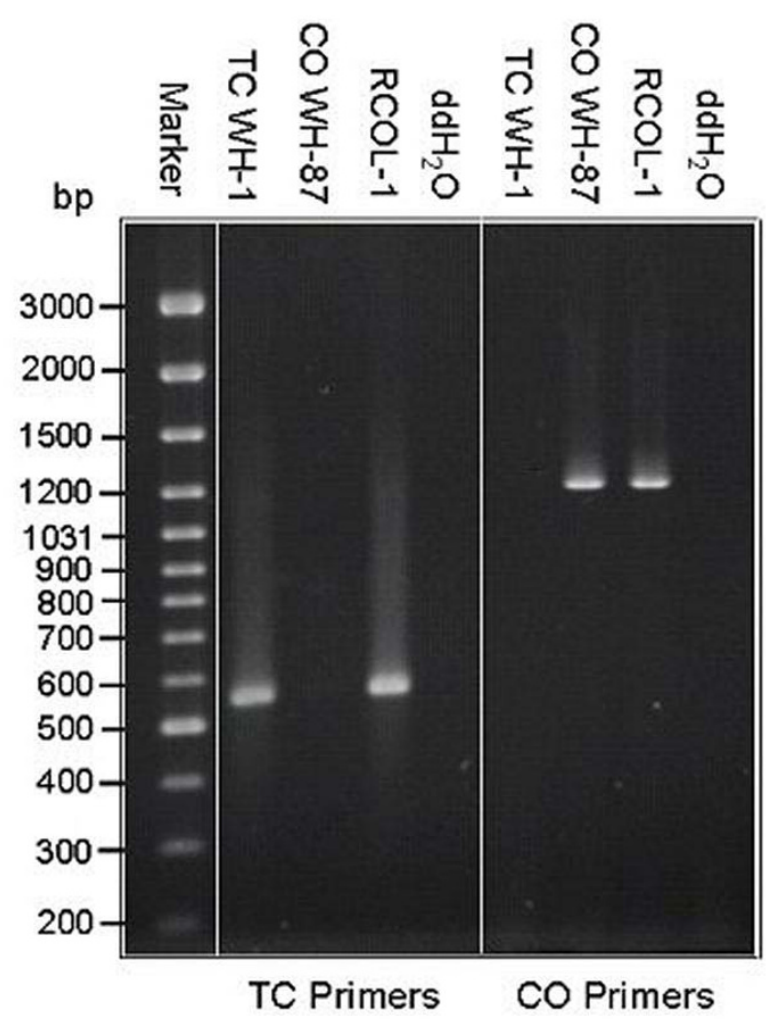

Figure 3

PCR identification of strain RCOL-I with specific primer pairs for Thanatephorus cucumeris (TC Primers: P-ITSI and GMRS-3) and for Ceratobasidium oryzae-sativa (CO primers: GMROS and R635). The genomic DNA of strain WH-I of T. cucumeris (TC WH-I) and strain $\mathrm{WH}-87$ of $C$. oryzae-sativa $(\mathrm{CO} \mathrm{WH-87)}$ were used as controls; $\mathrm{ddH}_{2} \mathrm{O}$ was used instead of DNA as reaction control. DNA weight marker is shown on the left.

primer pair RSITS1 (specific for ITS1 region of $T$. cucumeris) and ITS4 (non-specific). Clones were obtained, and 59 were tested with the primer pairs P-RSITS1-F and P-COITS2-R (for chimeric T. cucumeris ITS1 and C. oryzaesativae ITS2), and P-RSITS1-F and GMRS-3 (for pure T. cucumeris ITS), giving 46 and 13 clones, respectively. The ratio of chimeric clones to pure T. cucumeris clones in each test was between 3 to 3.5 implying that there are more copies of the chimeras than complete T. cucumeris ITS sequences. The greater abundance of chimeric sequences than pure T. cucumeris ITS sequences may be a result of crossing over events at the conserved $5.8 \mathrm{~S}$ gene, which sits between ITS1 and ITS2.

Hyphae of T. cucumeris and C. oryzae-sativae are vegetatively incompatible, and do not successfully anastomose. However, they parasitize the same host, and perhaps

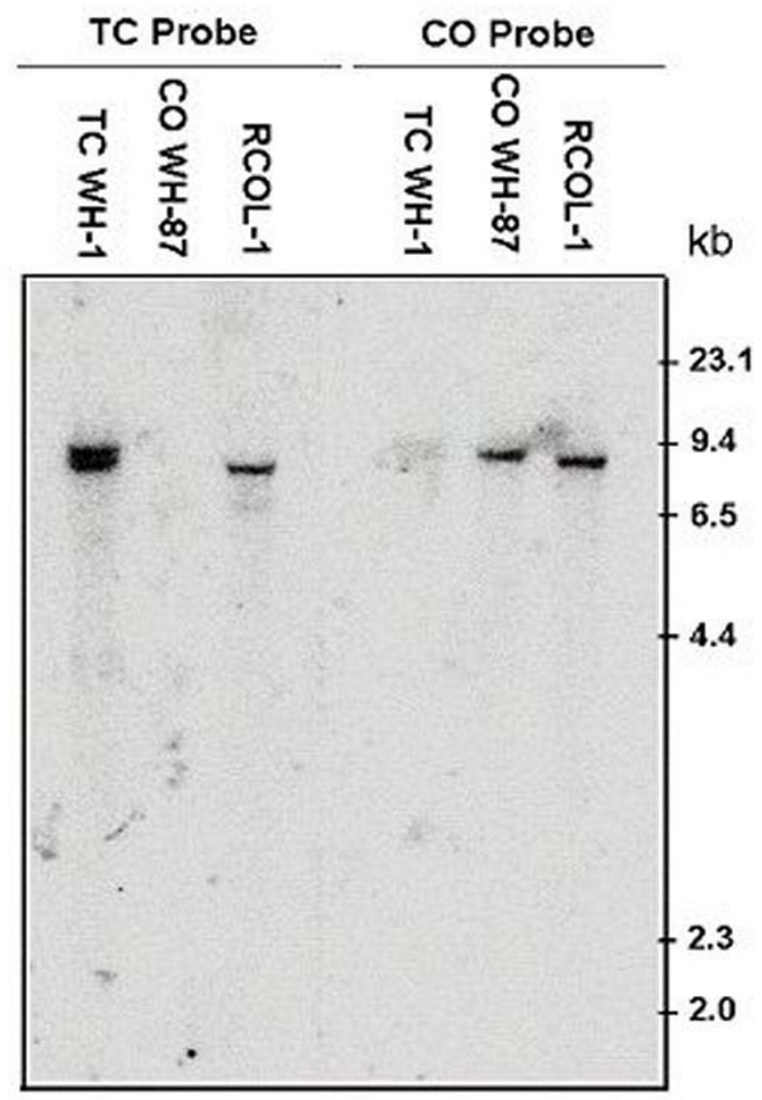

\section{Figure 4}

Southern blot analysis of the ITS DNA of strain

RCOL-I. Oligonucleotides derived from the ITSI sequences of Ceratobasidium oryzae-sativa (CO-Probe) or that of Thanatephorus cucumeris (TC-Probe) were 5'-32P labeled, and used as probes. Strain WH-I of T. cucumeris (TC WH-I) and strain WH-87 of $C$. oryzae-sativa were used as controls. The genomic DNA samples were digested completely with $\mathrm{BamH}$.

under the influence of host enzymes targeted to weaken pathogen cells or in dying host plant tissue, the fungal hyphae lost their integrity, and normal vegetative incompatibility mechanisms were overcome, allowing the hyphae to fuse. This direct intimate contact within the host could theoretically have lead to a transfer of genomic DNA between the fungi. Unlike plants and animals, vegetative cells of fungi are less differentiated, and each cell has the ability to develop into a new mycelium. This means that if any fungal cell were to obtain foreign DNA that was compatible with the DNA replication system, the cell could theoretically propagate the foreign DNA to daughter mycelia.

HGT was thought to be limited to the early stages of diverging lineages [21], although a review of more recent 


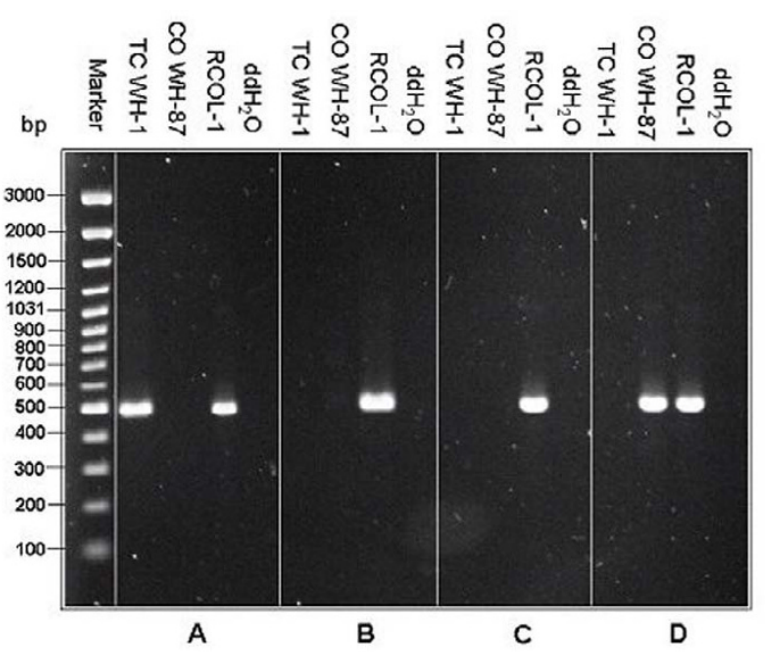

Figure 5

Strain RCOL-I contains four types of ITS DNA: (A) DNA amplified with P-RSITSI-F and GMRS-3; (B) DNA amplified with P-RSITSI-F and P-COITS2-R; (C) DNA amplified with P-COITSI-F and GMRS-3; and (D) DNA amplified with P-COITSI-F and P. COITS2-R. DNA weight marker is shown on the left.

literature [2] has found frequent HGT in some phagotrophic algae and HGT between plant lineages, with few examples for animals or fungi. The HGT event between $C$. oryzae-sativa and T. cucumeris which generated RCOL-1 was probably a relatively recent one, since such an abnormal isolate may be less fit and not have a high survival rate in nature. In July 2005, eight months after the initial isolation of RCOL-1, more intensive sampling was conducted in the field where RCOL-1 was originally collected, and three other strains with morphology similar to RCOL1 were found, although not at the original site of collection. This suggests that isolates such as RCOL-1 might be able to persist, even though macroscopically avirulent in pathogenicity tests, and with less aggressive growth than either parental type. Another explanation is that the intergeneric hybridization events occurred more than once in this field, and are more frequent than currently thought.

\section{Conclusion}

We hypothesize that a presumably rare anastomosis event between hyphae of $T$. cucumeris and C. oryzae-sativae allowed the transfer of nuclei into a C. oryzae-sativae mycelium, followed by nuclear fusion and crossing over events. The relative scarcity of $T$. cucumeris ITS sequences compared to $C$. oryzae-sativae, could be a result of the transfer of just a few nuclei from T. cucumeris into an extensive C. oryzae-sativae mycelium, or the subsequent process of concerted evolution (Elder and Turner 1995) to homogenize the ribosomal gene sequences. Species of
Rhizoctonia are known to be multinucleate, but the presence of chimeric forms of the ITS in RCOL-1 indicates that DNA of the two parental species had been mixed, rather than existing solely in separate nuclei. Furthermore, the growth debilitation and avirulence found with RCOL-1 are not likely to have resulted just from the altered ribosomal gene cassettes, since there are mostly pure copies of C. oryzae-sativae in RCOL-1, which should be sufficient for full function. There are probably other genes in RCOL-1 that have been affected by the intergeneric hybridization, giving the debilitated phenotype. Further research remains to reveal which other genes may have been affected, but the results of the current study indicate that horizontal gene transfer can occur between different genera of fungi, and based on the presence of other similarly debilitated field isolates, we speculate that such occurrences may not be so rare.

\section{Methods \\ Strains and medium}

RCOL-1, WH-1 and WH-87 were isolated from typical sheath blight lesions in a rice field at Huazhong Agricultural University, Wuhan, China. These isolates were subcultured numerous times from hyphal tips to ensure purity of each isolate. RCOL-1 grew slowly on PDA with abnormal colony morphology, while WH-1 and WH-67 were identified as normal strains of Thanatephorus cucumeris and Ceratobasidium oryzae-sativae respectively.

\section{DAPI staining of nuclei}

Strains were grown in PDA plates, and autoclaved glass slides were placed onto the agar. After hyphae grew onto the slides, a droplet of $0.004 \%$ DAPI was placed on each slide, followed by incubation in the dark for $20 \mathrm{~min}$. The nuclear type of each strain was observed with a Nikon fluorescence microscope fitted with an ultraviolet light filter.

\section{Primers and PCR amplification}

Fungal mycelia were collected and subjected to DNA extraction using the CTAB method [22]. Amplification of Internal transcribed spacers (ITS) was performed using primers P-ITS1 (5'-TCCGTAGGTGAACCTGCGG-3') and P-ITS4 (5'-TCCTCCGCTTATTGATATGC-3') according to [17]. Specific primers for distinguishing T. cucumeris and C. oryzae-sativae were designed and used based on Johanson et al [18]: GMRS-3 (5'-AGTGGAACCAAGCATAACACT-3') and P-ITS1 were used to specifically amplify DNA from T. cucumeris; and GMROS (5'-GAAAGAGAGAGAGGTCGCCTC-3') and R635 (5'-GGTCCGTGTTTCAAGACGG-3') were used to specific amply the DNA from $C$. oryzae-sativae.

To further analyze the PCR products of ITS DNA of RCOL1 , in addition to primer GMRS-3 (as a reverse primer for the ITS2 region of $T$. cucumeris), three more primers were 
designed based on the ITS sequence of C. oryzae-sativae and T. cucumeris: P-COITS1-F (5'-CCTTTCCTCCCAGG3'), P-COITS2-R (5'-GGAACCAAGTTCATAGA-3') and PRSITS1-F (5'-TCTACCTTAATTTGGC-3'). The two forward primers were paired with the two reverse primers giving four possible pairings. The genomic DNA of RCOL- 1 was amplified with P-ITS1 and P-ITS4, and the PCR product was purified and diluted 100 fold (about $1.0 \mathrm{ng} / \mu \mathrm{l}$ ) for second round amplification with the four pairs of primers. Amplification $(25 \mu \mathrm{l})$ were performed using $1.0 \mu \mathrm{l}$ purified PCR product, $2.5 \mu \mathrm{l}$ of $10 \times$ PCR buffer, $2.5 \mu \mathrm{l}$ of $2.5 \mathrm{mM}$ dNTPS, $1.0 \mu \mathrm{l}$ of $1.5 \mu \mathrm{M}$ forward primer and 1.0 $\mu \mathrm{l}$ of $1.5 \mu \mathrm{M}$ reverse primer, $0.25 \mu \mathrm{l}$ of $5.0 \mathrm{U} / \mu \mathrm{l}$ Taq (TAKARA, Dalian, P R China). A PCR amplification system (PTC-100: MJ, USA) was used with the following programme: initial denaturation for $4 \mathrm{~min}$ at $94^{\circ} \mathrm{C}, 30 \mathrm{~s}$ at $94^{\circ} \mathrm{C}, 30 \mathrm{~s}$ at $56^{\circ} \mathrm{C}, 30 \mathrm{~s}$ at $72^{\circ} \mathrm{C}, 20$ cycles; 7 min at $72^{\circ} \mathrm{C}$. PCR products were separated by electrophoresis on $1.2 \%$ $(\mathrm{w} / \mathrm{v})$ agarose gel, and stained in ethidium bromide.

\section{Southern hybridization}

To confirm the result obtained by PCR amplification, genomic DNA of strain RCOL-1, T. cucumeris strain WH-1 and C. oryzae-sativae WH-87 was extracted in CTAB following [22], and $15 \mu \mathrm{g}$ of DNA of each strain was digested completely with Bam $\mathrm{H} 1$, which does not have any recognition sites on the ITS or 5.8 S rDNA of these two fungi. The digested products were size-fractionated through a 0.8 $\%$ agarose gel and mounted onto positively charged nylon membranes. Two oligonucleotides, namely TC-Probe (5'CAATAGTTGGTGGATTTAATTCCATCATCCATTTGCTGT3') and CO-Probe (5'-TTTAACTAGGGAAAGAGAGAGAGGTCGCCTCCGTCTA-3') which were derived from the ITS1 sequence of T. cucumeris or C. oryzae-sativae, respectively, were synthesised and 5'-labelled with $\gamma$-32P ATP by T4 polynucleotide kinase as probes to hybridize with DNA of RCOL-1. Hybridization was conducted in a hybridization incubator (Biorad, USA). Briefly, the membranes were pre-hybridized in $3 \times$ SSC containing $0.1 \%$ SDS (sodium dodecyl sulfate) at $65^{\circ} \mathrm{C}$ for $7 \mathrm{~h}$ in a hybridization tube, and then probes were added into the hybridization buffer. Hybridization was carried out at $65^{\circ} \mathrm{C}$ overnight. To remove non-hybridized probes, membranes were washed in $100 \mathrm{ml}$ of $6 \times$ SSC containing $0.1 \%$ SDS three times for $15 \mathrm{~min}$, then in $100 \mathrm{ml}$ of $2 \times$ SSC containing $0.1 \%$ SDS for $10 \mathrm{~min}$, and finally in $100 \mathrm{ml}$ of $1 \times$ SSC containing $0.1 \%$ SDS for $5 \mathrm{~min}$. The temperature for washing was controlled at $60^{\circ} \mathrm{C}$. The membranes were exposed to an imaging plate and the locations of the labelled compounds were visualized by using a Molecular Dynamics (Sunnyvale, CA, USA) Strom-820 imaging-system analyzer.

\section{DNA sequencing}

PCR products at various stages of this study were fractionated by electrophoresis in agarose gels and purified using a Gel Extraction Kit (Sangon, Shanghai, P R China). The recovered DNA was ligated onto T-Vector (pMD-18, TAKARA, Dalian, P R China), and then transformed into competent cells of E. coli JM109. Sequencing was done by the dideoxy-nucleotide termination method using the Big Dye terminator Sequencing Kit (BigDye terminator v2.0) and an ABI PRISM 377-96 automated sequencer (Sangon, Shanghai, P.R. China). The M13 universal primer was used for sequencing.

\section{List of Abbreviations}

bp - Base pair, CTAB - Cetyl trimethylammonium bromide, DNA - Deoxyribonucleic acid, HGT - Horizontal gene transfer, ITS - Internal transcribed spacer region of rDNA, PCR - Polymerase chain reaction, rDNA - Ribosomal DNA, rRNA - Ribosomal RNA, SDS - Sodium dodecyl sulphate, SSC - A solution consisting of $0.15 \mathrm{M}$ sodium chloride and $0.015 \mathrm{M}$ trisodium citrate

\section{Authors' contributions}

DJ, YF, TH and YP designed the experimental strategy; IX, YF, BL, DJ conducted the experiments; DJ, YF, JX, TH, YP, GL and JH were involved in the data analysis and their processing; and DJ and TH wrote the manuscript. All authors approve of the final manuscript.

\section{Acknowledgements}

This work was supported by the National Basic Research Program of China (973 Program) (2006CB I0I90I-I), and the Natural Sciences and Engineering Council of Canada.

\section{References}

I. Ochman H, Lawrence JG, Groisman EA: Lateral gene transfer and the nature of bacterial innovation. Nature 2000, 405:299-304.

2. Andersson JO: Lateral gene transfer in eukaryotes. Cell Mol Life Sci 2005, 62: 1 182-1197.

3. Choi IG, Kim SH: Global extent of horizontal gene transfer. PNAS 2007, 104:4489-4494.

4. Rosewich UL, Kistler HC: Role of horizontal gene transfer in the evolution of fungi. Annual Review of Phytopathology 2000, 38:325-363.

5. Garcia-Vallvé S, Romeu A, Palau J: Horizontal gene transfer of glycosyl hydrolases of the rumen fungi. Mol Biol Evol 2000, 17:352-361.

6. Richards TA, Dacks JB, Jenkinson JM, Thornton CR, Talbot NJ: Evolution of filamentous plant pathogens: Gene exchange across eukaryotic kingdoms. Current Biology 2006, 16:1857-1864.

7. Brinkman FSL, Macfarlane EL, Warrener P, Hancock REW: Evolutionary relationships among virulence-associated histidine kinases. Infect Immun 200I, 69:5207-52II.

8. Klotz MG, Loewen PC: The molecular evolution of catalatic hydroperoxidases: Evidence for multiple lateral transfer of genes between prokaryota and from bacteria into eukaryota. Mol Biol Evol 2003, 20:1098-I I I2.

9. Wenzl P, Wong L, Kim K, Jefferson RA: A functional screen identifies lateral transfer of $\beta$-Glucuronidase (gus) from bacteria to fungi. Mol Biol Evol 2005, 22:308-316.

10. Wei W, McCusker JH, Hyman RW, Jones T, Ning Y, Cao Z, Gu Z, Bruno D, Miranda M, Nguyen M, Wilhelmy J, Komp C, Tamse R, Wang $X$, jia P, Luedi P, Oefner PJ, Davis L, Dietrich FS, Li Y, Davis $R W$, Steinmetz LM: Genome sequencing and comparative anal- 
ysis of Saccharomyces cerevisiae strain YJM789. PNAS 2007, 104: $12825-12830$

11. He C, Rusu AG, Poplawski AM, Irwin JAG, Manners JM: Transfer of a supernumerary chromosome between vegetatively incompatible biotypes of the fungus Colletotrichum gloeosporioides. Genetics 1998, 150:1459-| 466.

12. Patron NJ, Waller RF, Conzijnsen AJ, Straney DC, Gardiner DM, Nierman WC, Howlett BJ: Origin and distribution of epipolythiodioxopiperazine (ETP) gene clusters in filamentous ascomycetes. BMC Evol Biol 2007, 7:174.

13. Slot JC, Hibbett DS: Horizontal transfer of a nitrate assimilation gene cluster and ecological transitions in fungi: a phylogenetic study. PLoS One 2007, 2:el097.

14. van der Does HC, Rep M: Virulence genes and the evolution of host specificity in plant-pathogenic fungi. Mol Plant Microbe Interact 2007, 20:1175-1 I82.

15. Temporini ED, VanEtten HD: An analysis of the phylogenetic distribution of the pea pathogenicity genes of Nectria haematococca. Curr Genet 2004, 46:29-36.

16. Hershkovitz MA, Zimmer EA, Hahn W]: Ribosomal DNA and angiosperm systematics. In Molecular Systematics and Plant Evolution Edited by: Hollingsworth P, Bateman R, Gornall R. Taylor \& Francis; 1999:268-326.

17. White TJ, Bruns T, Lee S, Taylor JW: Amplification and direct sequencing of fungal ribosomal RNA genes for phylogenetics. San Diego, CA: Academic Press; 1990.

18. Johanson A, Turner HC, Mckay GJ, Brown AE: A PCR-based method to distinguish fungi of rice sheath-blight complex, Rhizoctonia solani, $\boldsymbol{R}$. oryzae and $\boldsymbol{R}$. oryzae-sativae. FEMS Microbiol Lett 1998, 162:289-294.

19. Plamann M, Minke PE, Tinsley JH, Bruno KS: Cytoplasmic dynein and actin-related protein Arpl are required for norma nuclear distribution in filamentous fungi. J Cell Biol 1994, | 27:|39-|49.

20. Sneh B, Burpee L, Ogoshi A: Identification of Rhizoctonia species. APS Press, St Paul, MN, USA 1991.

21. Woese CR: The universal ancestor. PNAS 1998, 95:6854-6859.

22. Sambrook J, Frisch EF, Maniatis T: Molecular Cloning: A Laboratory Manual second edition. Cold Spring Harbor Laboratory, Cold Spring Harbor, NY; 1989.

Publish with Biomed Central and every scientist can read your work free of charge

"BioMed Central will be the most significant development for disseminating the results of biomedical research in our lifetime. "

Sir Paul Nurse, Cancer Research UK

Your research papers will be:

- available free of charge to the entire biomedical community

- peer reviewed and published immediately upon acceptance

- cited in PubMed and archived on PubMed Central

- yours - you keep the copyright 